\title{
Living Alquran dan Hadis di Pesantren Darul Arafah Raya
}

\author{
Saiful Akhyar Lubis ${ }^{1}$, Syaukani ${ }^{1}$, Nurhafizah Simamora ${ }^{1}$, Rahmadi Ali ${ }^{2}$ \\ ${ }^{1}$ Universitas Islam Negeri Sumatera Utara Medan \\ ${ }^{2}$ Universitas Muslim Nusantara Al Washliyah Medan \\ Email: ${ }^{1}$ nurhafizah0516@gmail.com, ${ }^{2}$ rahmadi_ali21@yahoo.com
}

\begin{abstract}
ABSTRAK
Living Quran dan Hadis (Alquran dan Hadis yang hidup) adalah resepsi dan respon masyarakat dalam praktik makna Alquran dalam kehidupan masyarakat. Tujuan penelitian ini ingin melihat bagaimana studi living Alquran dan Hadis di Pesantren Darul Arafah Raya dan apa saja nilai-nilai pendidikan di lingkungan Pesantren Darul Arafah Raya. Penelitian lapangan (Field research) ini menggunakan metode kualitatif yang sifatnya deskriptif dengan teknik observasi, wawancara dan dokumentasi, Penelitian ini dilaksanakan di Pesantren Darularafah Raya. Adapun hasil penelitian ini (1) Studi living Alquran di Pesantren Darul Arafah Raya di antaranya adalah: Alquran dibaca rutin dan diajarkan di tempat-tempat ibadah, Alquran senantiasa dihafalkan, potongan ayat Alquran dikutip dan dibentuk kaligrafi, dan Ayat-ayat Alquran dibaca oleh para qari, (2) Studi living hadis di Pesantren Darul Arafah Raya melestarikan otentitas tradisi tulisan, tradisi lisan, dan tradisi praktik. (3) Nilai-nilai pendidikan di lingkungan Pesantren Darul Arafah Raya berupa nilai tauhid, nilai ibadah, nilai akhlak dan Nilai kemasyarakatan
\end{abstract}

Kata Kunci: Living alquran dan Hadis, Pesantren Darul Arafah Raya

\begin{abstract}
The Living Quran and Hadith (the living Alquran and Hadith) are people's reception and response to the practice of the meaning of the Koran in the midst of people's lives. The purpose of this research is to see how the study of living Alquran and hadith in the Darul arafah Raya pesantren and what are the educational values in the Darul arafah Raya pesantren environment. This field research (Field research) uses qualitative methods that are descriptive in nature with observation, interview and documentation techniques. This research was conducted at the Darularafah Raya Islamic Boarding School. The results of this study (1) The study of living Alquran at Pesantren Darul Arafah Raya includes: one or several certain verses are quoted and formed in calligraphy, and the verses of the Koran are read by the reciters, (2) The study of living hadith in Pesantren Darul Arafah Raya maintains the authenticity of written traditions, oral traditions, and practice traditions. (3) Educational values within the Darul arafah Raya pesantren are in the form of monotheistic values, worship values, moral values, and social values.
\end{abstract}

Keywords: Living alquran and Hadith, Darul Arafah Raya Islamic Boarding School

\section{Pendahuluan}

Alquran adalah kitab suci umat Islam yang begitu Indah dari sisi kebahasaan dan memiliki daya tarik untuk dibahas. Berinteraksi dengan Alquran adalah sebuah pengamalan yang berharga bagi Muslim. Pengamalan berinteraksi dengan 
Alquran bisa melalui lisan, tulisan, maupun perbuatan. Baik yang berupa pemikiran, emosional dan spiritual (Sulastri Tanasa, dkk, 2019: 1-9)

Alquran merupakan kalam suci (kallamullah)( Yunahar Ilyas, 2013: 16) yang diakui keabsahannya sebagai pedoman umat Islam (didik hermawan, 2018: 2735). Alquran juga merupakan bahagian dari mukjizat yang di peroleh Nabi Muhammad SAW melalui ruhul qudus (M. Quraish Shihab, 1997: 23). Adapun segala asas kebenarannya, umat Islam mendapatkan nilai ibadah "pahala" bagi yang membaca “Alquran” dan mentadabburinya (Hafidz dan Ahsin Wijaya, 2008: 18). Oleh karenanya urgensitas dalam fardu kifayah telah di nisbatkan kepada umat Islam yaitu dengan menjaga dan merawat otentitas kitab sucinya berdasarkan hafalan terhadap Alquran. Upaya pemeliharaan tersebut banyak di contohkan oleh Nabi Muhammad SAW. Sehingga kontekstualitasnya masih eksis pada masa kini (Ismail Fahmi Arrauf Nasution, 2018: 225).

Ummat Islam percaya bahwa Alquran merupakan puncak dan penutup wahyu Allah yang diperuntukkan bagi manusia dan bagian merupakan bagian dari rukun iman yang disampaikan kepada Nabi Muhammad saw melalui perantara ruhul qudus (Jibril).

Mengkaji Alquran sampai saat masih menjadi bagian terpenting dalam upaya mempelajari Islam. Tentunya model pengkajiannya pun sangat berperan supaya mendapatkan hasil dan tujuan yang optimal. Salah satu wacana kontemporer dalam studi Alquran adalah kajian yang dikenal dengan living quran.

Secara sederhana, "living Quran" dapat dimaknai sebagai gejala yang nampak di masyarakat berupa pola-pola prilaku maupun respons sebagai pemaknaan terhadap nilai-nilai qurani. Karya yang berhasil digoreskan oleh peneliti Alquran yang mengkaji tentang living quran adalah karya antropolog Heddy Shri Ahimsa Putraberjudul "Menafsir Alquran yang Hidup, Memaknai alquranisasi Kehidupan"dan melalui pendekatan sosial-budaya, beliau dalam karyanya memaparkan bahwa fenomena yang muncul dari berbagai pemaknaan orang terhadap Alquran sebagai sebuah kitab yang berisi firman-firman Allah Swt dan bagaimana pemaknaan itu kemudian mewujud dalam kehidupan sehari-hari. 
Pada porsi yang lain diskursus mengenai hadis secara konseptual, bahwa living hadis memiliki atensi sentral dalam penelitian. Living hadis adalah kajian atau penelitian ilmiah tentang berbagai peristiwa sosial terkait dengan kehadiran atau keberadaan hadis di sebuah komunitas muslim tertentu (M. Mansur, 2007: 8). Dari sana akan terlihat respon sosial (realitas) komunitas muslim untuk membuat hidup dan menghidup-hidupkan teks-teks agama melalui sebuah interaksi yang berkesinambungan (Adrika Fithrotul Aini, 2014: 24).

Hadis yang menyebar dikalangan umat Islam kemudian diaktualisasikan dalam konteks tradisi dan budaya lokal inilah yang disebut dengan living hadis. Menurut Nurun Najwah bahwa kajian tentang fenomena sosial muslim yang termasuk dalam kajian living hadis adalah aktivitas yang dikaitkan oleh si pelaku sebagai aplikasi dari meneladani Nabi atau dari teks-teks hadis (sumber-sumber yang jelas) atau yang diyakini ada (Nurun Najwah, 2007: 134). Dengan adanya upaya mengaplikasikan hadis dalam kehidupan sehari-hari maka dapat dikatakan living Hadis merupakan hadis yang hidup didalam masyarakat (M. Alfatih Suryadilaga, 2007: 106).

Seiring perkembangan zaman, kajian mengenai Alquran dan Hadis mengalami pengembangan wilayah kajian. Dari kajian teks menjadi kajian sosialbudaya, yang menjadikan masyarakat sebagai objeknya. Kajian ini sering disebut dengan istilah "living Quran" dan "living Hadis". Peran akademisi sebagai prototipe intelektual harus memiliki kekayaan metapora dalam menganalisis pada konteks luas. Untuklah itu peneliti ingin menyahuti panggilan intelektual dari penelitian "living Quran" dan "living Hadis". Dengan melaksanakan penelitian di Pesantren Darularafah Raya.

Pesantren Darul Arafah Raya adalah sebuah pesantren khalafi (modern) yang terletak di Desa Kutalimbaru, Kabupaten Deli Serdang, berjarak sekitar kurang lebih $25 \mathrm{~km}$ dari pusat kota Medan, Sumatera Utara. Peletakan batu pertama pendidikan Pesantren Darul Arafah Raya dilakukan pada 17 Agustus 1985 oleh Bapak Amrullah Naga Lubis dan keluarga bersama beberapa guru alumni Pesantren Gontor. Pada tanggal 8 Mei 1986 bertepatan dengan 26 Sya "ban 
1706 dibuka pendaftaran untuk pertama kalinya bagi santri (khusus putra) angkatan I (pertama) di Pesantren Darularafah Raya.

Sebagaimana pelajar di Pesantren Darul Arafah Raya, pada saat saya melakukan wawancara dengan bapak Nirwansyah selaku kepala sekolah. Bahwa di Pesantren Darul Arafah Raya terdapat pelajaran Al-Qur'an dan Hadist. Akan tetapi dalam pelajaran tersebut para siswa memiliki tingkat respon yang berbedabeda. Ada yang bisa membaca tetapi tidak tahu artinya, ada juga yang bisa membaca dan tahu artinya akan tetapi belum bisa mengamalkannya. Dengan berbagai macam respon yang ada saya sebagai peneliti tertarik mengadakan penelitian di Pesantren Darul Arafah Raya. Penulis ingin mengetahui sejauh mana pelajaran Al-Qur'an dan Hadist diaplikasikan oleh siswa dengan merumuskan sebuah masalah bagaimana studi living al-qur'an dan hadis di pesantren darul arafah raya dan apa saja nilai-nilai pendidikan di lingkungan pesantren darul arafah raya.

Penelitian ini termasuk penelitian lapangan (Field Research). Penelitian lapangan yaitu penelitian yang pengumpulan datanya dilakukan di lingkungan masyarakat, lembaga-lembaga, dan organisasi kemasyarakatan dan lembaga pendidikan formal maupun non formal. Penelitian ini bersifat penelitian kualitatif. Penelitian kualitatif dapat membantu peneliti untuk memperoleh jawaban atas suatu gejala, fakta dan realita yang dihadapi sekaligus memberikan pemahaman dan pengertian baru atas masalah tersebut sesudah menganalisis data yang ada. Menurut Bogdan \& Taylor penelitian kualitatif adalah prosedur penelitian yang menghasilkan data deskriptif, yaitu ucapan atau tulisan dan perilaku yang dapat diamati dari orang-orang (subyek) itu sendiri (Lexy J. Moleong, 2010: 4). Sesuai dengan prinsip epistemologinya, penelitian kualitatif biasa menelaah hal-hal yang berbeda dalam lingkungan alamiahnya, berusaha memahami atau menafsirkan fenomena berdasarkan makna-makna yang orang berikan kepada hal-hal tersebut. Penelitian ini dilaksanakan di Pesantren Darul Arafah Raya yang beralamat di jl. Berdikari, Desa Lau Bakeri kecamatan Kutalimbaru Kabupaten Deli Serdang Provinsi Sumatera Utara. 


\section{Pembahasan}

\section{1) Living Quran}

Menurut Muhammad Mansur bahwa Living Quran pada hakekatnya bermula dari fenomena Quran in Everyday Life, yakni makna dan fungsi Alquran yang riil dipahami dan dialami masyarakat muslim (Sahiron Syamsuddin, 2007: 5). Maksud Muhammad Mansur adalah "perilaku masyarakat yang dihubungkan dengan Alquran pada tataran realitas, di luar maqasid an-nas". Alquran mempunyai fungsi sesuai dengan apa yang bisa dianggap atau dipersepsikan oleh satuan masyarakat dengan beranggapan akan mendapatkan "fadillah" dari pengamalan yang dilakukan dalam tataran realitas yang dijustifikasi dari teks Alquran. Living Quran juga merupakan fenomena yang hidup di tengah masyarakat Muslim terkait dengan Alquran ini sebagai objek studinya”. Maka dari itu pembahasan living quran merupakan kajian tentang "berbagai peristiwa sosial terkait dengan kehadiran Alquran atau keberadaan Alquran di sebuah komunitas Muslim tertentu".

\section{2) Living Hadis}

Hadis adalah sumber kedua setelah Alquran yang dijadikan pedoman hidup dan ajaran yang terdapat di dalamnya diamalkan oleh umat Islam. Ia menjadi standar faktual umat Islam dalam usaha meneladani dan mempraktikkan petunjuk Rasulullah Saw. Bagi umat Islam Nabi Muhammad SAW suri tauladan yaitu sosok yang dapat dijadikan panutan dalam kehidupan sehari-hari (perbuatan, perkataan maupun penetapan Nabi sebagai pedoman ke-dua setelah Alquran).

Pada periode awal Nabi Muhammad SAW senantiasa memberikan arahan kepada ummatnya tentang kebenaran maupun norma-norma yang terkandung dalam Alquran. Sabda Nabi tidak lepas dari situasi dan kondisi yang melingkupi masyarakat waktu itu, sehingga sangat kecil kemungkinan jika Nabi bersabda tanpa adanya problem atau masalah yang mendasar (Abdul Mustaqim, 2008: 5).

Hadis secara harfiah 'hadis' berarti "berbicara", "perkataan" atau "percakapan", sedangkan dalam terminologi Islam istilah hadis bermakna 
melaporkan dan mencatat sebuah pernyataan dan tingkah laku dari Nabi Muhammad Saw. Sedangkan menurut ulama ahli hadis, hadis yaitu apa yang diriwayatkan dari Nabi, baik perkataan, perbuatan ataupun ketetapannya ( تقري), sifat jasmani atau sifat akhlak, perjalanan setelah diangkat sebagai Nabi (Arab: ( بعثة dan terkadang juga sebelumnya, sehingga arti hadis di sini semakna dengan sunnah. Kata hadis yang mengalami perluasan makna disinonimkan dengan sunnah, maka pada saat ini bisa saja berarti segala perkataan (sabda), perbuatan, ketetapan maupun persetujuan dari Nabi Muhammad Saw dijadikan ketetapan ataupun hukum.

\section{1) Studi living Alquran di pesantren Darul Arafah Raya}

Ketika Alquran diturunkan, maka Rasulullah adalah sosok yang paling "bertanggung jawab" untuk menyampaikan pesan-pesan moral yang tersurat dan tersirat di dalamnya (Alquran), sebagai pembawa risalah. Rasulullah diberi otoritas penuh oleh Allah swt, untuk menjelaskan pesan wahyu kepada umatnya ketika mereka mendapatkan kesulitan dalam memahami teks wahyu (Muhammad Husein Al Dzahabi: 33).

Rasulullah dalam kondisi tertentu juga meresepsi alquran secara fungsional. Dalam konteks ini, beliau menjadikan ayat-ayat suci alquran sebagai terapi atau yang populer dengan sebutan ruqyah. Misalnya, Rasulullah pernah membaca surat mu'awwizatain, kemudian ditiupkan pada telapak tangannya dan digosokkan pada tubuhnya pada saat beliau sakit sebelum meninggal (Al Bukhari)

Fathurrosyid, membagi resepsi Alquran ke dalam 3 bagian:

a. Resepsi Eksegesis terhadap Alquran yaitu Alquran dibaca, dipahami dan diajarkan.

b. Resepsi Estetis terhadap Alquran yaitu Alquran dituliskan sebagai kaligrafi atau tulisan dinding. baik berupa potongan ayat atau surat.

c. Resepsi Fungsional terhadap Al-Qur'an yaitu di mana Qur'an dijadikan sebagai benda yang mempunyai kekuatan magis. Potongan ayat-ayat al Qur'an apabila dibaca secara rutin dan konsisten, baik waktu dan 
tempatnya, maka akan mendatangkan kekuatan, sebagai penolak bala, atau sebagai penarik rizki dan lainnya (Fathurrosyid, 225-231).

Masyarakat Muslim memiliki keyakinan bahwa kehadiran Alquran tidak saja sebagai kitab petunjuk (hudan), tetapi juga berfungsi secara fungsional yang mempunyai kekuatan mistis. Alquran sendiri memproklamirkan dirinya secara gamblang sebagai syifa' li al nas dan syifa' lima fi al shudur. Karena itu,bukan tidak mungkin masyarakat muslim meresepsi Alquran secara Fungsional dan menjadikan amaliyah, wirid dan dzikir untuk mengusir roh jahat, semisal jin dan fenomena mistis lainnya serta juga dijadikan jimat untuk penglaris dagangan dan sebagainya.

Dari hasil penelitian penulis beberapa gambaran Living Quran yang keberadaannya sering kita jumpai di lingkungan pesantren bahkan dimasyarakat umum adalah sebagai berikut:

\section{a) Alquran dibaca rutin dan diajarkan di tempat-tempat ibadah}

Berdasarkan hasil wawancara kepada pengurus Pondok Pesantren Darul Arafah, beliau menyatakan bahwa untuk menanamkan nilai-nilai di Pondok Pesantren Darul Arafah di lakukan dengan melakukan bimbingan baca Alquran. Pelaksanaan program bimbingan baca Alquran yang di lakukan di Pondok Pesantren Darul Arafah merupakan program pengembangan potensi di bidang agama agar nanti output dari santrinya bisa memahami dan mengamalkan ajaran Islam dengan baik. Maka dari itu, pondok pesantren mengupayakan agar para santrinya mampu membaca kitab suci Alquran dengan baik dan benar.

Berkaitan dengan jadwal pelaksanaan bimbingan baca tulis Alquran di Pondok Pesantren Darul Arafah peneliti mencari sumber data melalui interview dengan pengurus asrama laskar Quran di Pondok Pesantren Darul Arafah. Beliau mengatakan bahwa: "program bimbingan baca tulis Alquran di laksanakan setiap hari setelah Sholat ashar dan isya di bimbing langsung oleh ustadz/ ustadzah yang memiliki keahlian dan kemampuan dalam bidang baca tulis Alquran. Untuk mempermudah proses bimbingan oleh para mentor kepada para santri, maka santri dibagi dalam beberapa kelas sesuai dengan tingkatan masing-masing, agar para mentor tidak merasa kesulitan dalam memberikan materi pelajaran. 
Tujuan adanya bimbingan baca tulis teks Alquran pada prinsipnya di sesuaikan dengan kurikulum yang berlaku, yakni agar santri mampu membaca Alquran dengan baik dan benar, santri hafal surat-surat pendek dari Alquran dan mampu menulis atau menyalin ayat.

Artinya: "Dan seandainya pohon-pohon di bumi menjadi pena dan laut (menjadi tinta), ditambahkan kepadanya tujuh laut (lagi) sesudah (kering)nya, niscaya tidak akan habis-habisnya (dituliskan) kalimat Allah. Sesungguhnya Allah Maha Perkasa lagi Maha Bijaksana.” (QS. Luqman: 27).

\section{b) Alquran senantiasa dihafalkan}

Berdasarkan hasil wawancara dengan pembimbing tahfiz Alquran yaitu ustadzah masriati: "untuk mendapatkan hasil yang memuaskan Pada umumnya pembimbing tahfiz menerapkan metode hafalan. Hafalan ini di terapkan pada materi yang bersifat natsar maupun nadzom serta materi-materi lainya yang di tentukan seperti yasin, waqiah, juzz amma. Metode ini di terapkan pada santri baru maupun yang lama jadi semua santri di tuntut untuk menghafal.

Ada bebarapa metode yang mungkin bisa diterapkan dalam rangka mencari alternatif terbaik untuk menghafal Alquran dan bisa memberi bantuan kepada para penghafal dalam mengurangi kesusahan dalam menghafal Alquran. Metode-metode tersebut antara lain.

a) Metode wahdah yaitu metode menghafal Alquran dengan cara menghafal ayat satu-persatu. Untuk mencapai hafalan awal, setiap ayat bisa dibaca dan diulang sebanyak sepuluh kali atau dua puluh kali atau lebih sehingga proses ini mampu membentuk pola dalam bayangannya. Dengan demikian penghafal akan mampu mengkondisikan ayat-ayat yang dihafalkannya bukan saja dalam banyangannya, akan tetapi hingga benar-benar repleks pada lisannya setelah benar-benar hafal barulah dilanjutkan pada ayat-ayat berikutnya dengan cara yang sama.

b) Metode kitabah yaitu metode menghafal Alquran dengan cara menuliskan ayat-ayatnya. Metode ini memberikan alternatif lain dari pada metode yang pertama. Pada metode ini penghafal terlebih dahulu menulis ayatayat yang akan dihafalnya pada kertas yang telah disediakan untuknya. Kemudian ayat-ayat tersebut dibaca lalu dihafalkannya. Menghafalnya 
bisa dengan metode wahdah atau dengan berkali-kali menuliskannya sehingga ia dapat memperhatikan dan menghafalkannya dalam hati. Berapa banyak ayat tersebut ditulis tergantung kemampuan penghafal. Munkin cukup sekali, dua kali atau tiga kali atau mungkin sampai sepuluh kali atau lebih sehingga ia benar-benar hafal terhadap ayat yang dihafalnya.

c) Metode Sima'i yaitu metode menghafal Alqura dengan cara mendengar. Yang dimaksud dengan metode ini adalah mendengar sesuatu bacaan untuk dihafalkannya. Metode ini akan sangat efektif bagi penghafal yang mempunyai daya ingat ekstra, terutama bagi penghafal tunanetra, atau anak-anak yang masih di bawah umur yang belum mengenal tulis baca Alquran. Metode ini dapat dilakukan dengan dua alternatif: pertama mendengar dari guru yang membimbingnya, terutama bagi penghafal tunanetra, atau anak-anak. Dalam hal seperti ini, intruktur dituntut untuk lebih berperan aktif, sabar dan teliti dalam membacanya dan membimbingnya, karena ia harus membacakan satu per satu ayat untuk dihafalnya, sehingga penghafal mampu menghafalnya secara sempurna. Yang kedua merekam terlebih dahulu ayat-ayat yang akan dihafalnya ke dalam pita kaset sesuai dengan kebutuhan dan kemampuannya. Kemudian kaset diputar dan didengar secara seksama sambil mengikutinya secara perlahan-lahan. Kemudian diulang lagi dan diulang lagi, dan seterusnya menurut kebutuhan sehingga ayat-ayat tersebut benar-benar hafal di luar kepala. Setelah hafalan dianggap cukup mapan barulah berpindah kepada ayat-ayat berikutnya dengan cara yang sama. Metode ini akan sangat efektif untuk anak-anak, tunanetra atau penghafal mandiri.

d) Metode Gabungan. Metode ini merupakan gabungan antara metode pertama dan metode kedua, yaitu metode wahdah dan metode kitabah. Hanya saja kitabah di sini lebih memilki fungsional sebagai uji coba terhadap ayat-ayat yang telah dihafalnya, maka dalam hal ini, setelah penghafal selesai menghafal ayat yang dihafalnya, kemudian ia mencoba menuliskannya di atas kertas yang telah disediakan untuknya dengan 
hafalan pula. Jika ia telah mampu mereproduksi kembali ayat-ayat berikutnya, tatapi jika penghafal belum mampu mereproduksi hafalannya ke dalam tulisan secara baik, maka ia kembali menghafalnya sehingga ia benar-benar mencapai nilai hafalan yang valid. Kelebihan metode ini adalah adanya fungsi ganda, yakni berfungsi untuk menghafal dan sekaligus berfungsi untuk pemantapan hafalan.

e) Metode Jama' yaitu metode menghafal Alquran secara kolektif, yakni ayat-ayat yang dihafal dibaca secara kolektif atau bersama-sama, dipimpin oleh seorang intruktur. Pertama, instruktur membacakan satu ayat atau beberapa ayat dan siswa menirukan secara bersama-sama. Kemudian intruktur membimbingnya dengan mengulang kembali ayat-ayat tersebut dan siswa mengikutinya. Setelah ayat-ayat itu dapat mereka baca dengan baik dan benar, selanjutnya mereka mengikuti bacaan instruktur dengan sedikit demi sedikit mencoba melepaskan mushaf (tanpa melihat mushaf) dan demikian seterusnya sehingga ayat-ayat yang sedang dihafalnya itu benar-benar sepenuhnya masuk dalam bayangannya. Setelah semua siswa hafal, barulah kemudian diteruskan pada ayat-ayat berikutnya dengan cara yang sama (Ahsin W. Al-Hafidz, 2003: 63-66).

\section{2) Menjadikan Potongan Ayat, Satu Atau Beberapa Ayat Tertentu Dibentuk Kaligrafi}

Kaligrafi merupakan seni yang menggunakan alat tulis/tinta agar dapat menghasilkan tulisan yang indah. Bahkan bukan hanya mengandung nilai estetik tetapi juga mengandung nilai spiritualitas. Kaligrafi yang dimaksud biasanya berupa kaligrafi Arab (khatt) yaitu tulisan-tulisan yang indah dari bahasa Arab yang diambil dari potongan-potongan ayat Alquran, hadis-hadis, dan kata-kata hikmah para ulama yang bijaksana. Khat adalah suatu ilmu yang memperkenalkan bentuk huruf-huruf tunggal, letak-letaknya dan cara-cara merangkainya menjadi sebuah tulisan yang tersusun atau apa-apa yang ditulis di atas garis-garis, bagaimana cara menulisnya, dan menentukan mana yang perlu ditulis, mengubah ejaan yang perlu diubah, dan menentukan bagaimana cara mengubahnya. 
Penulis dapat menarik kesimpulan bahwa kaligrafi adalah ilmu yang mempelajari tentang tata cara menulis huruf-huruf Arab dengan benar sesuai dengan kaidah-kaidah yang mengaturnya. Kaidah disini yang dimaksud adalah aturan yang harus dipatuhi oleh seorang penulis kaligrafi agar tulisan yang dihasilkan memenuhi standar, sebagai tulisan yang diakui kebenarannya. Berdasarkan hasil wawancara penulis dengan Ustadz Waiji Samiono S.Pd.I mengatakan bahwa:

"Jenis kaligrafi terbagi menjadi dua, yakni kaligrafi murni dan kaligrafi lukisan. Kaligrafi murni adalah kaligrafi yang mengikuti pola-pola kaidah yang sudah ditentukan dengan ketat. Yakni bentuk yang tetap berpegang pada rumus-rumus dasar kaligrafi yang baku. Sedangkan kaligrafi lukisan adalah model kaligrafi yang digoreskan pada hasil karya lukis, atau lukisan kaligrafi yang dilukis-lukis sedemikian rupa tanpa mau terikat dengan rumusrumus baku yang telah ditentukan".

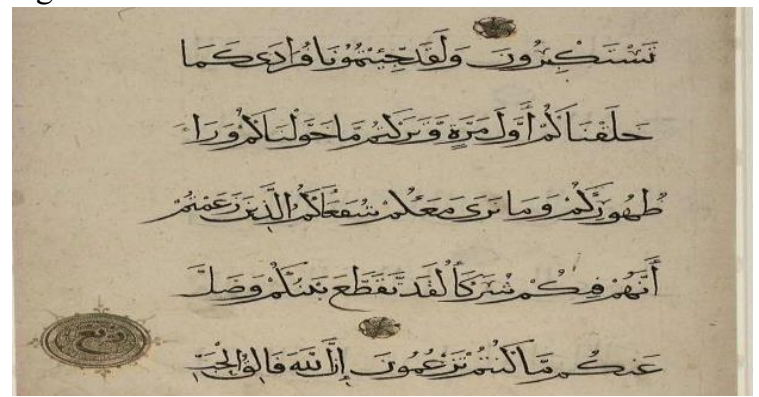

Gambar 1. Contoh karya lukis khatt Muhaqqaq santri Di Pesantren Darul Arafah Raya (Dokumentasi, Simamora 04 Februari 2020 pukul 08.00 WIB)

Hasil karya kaligrafi santri ini merupakan bagian dari kaligrafi Islam murni. Santri diharapkan mampu menjaga kelestarian khat sesuai dengan ketentuan yang berlaku. Secara esensial Waiji Samiono mengafirmasi:

\footnotetext{
"mengajarkan seni kaligrafi sama dengan berusaha memproduksi manusia-manusia yang berbudi, sekaligus memberikan jalan untuk memilihkan sumber-sumber ekonomi yang baik, seperti dikatakan seorang penyair, ,Pelajarilah kaligrafi yang betul, wahai orang yang memiliki akal budi, karena kaligrafi itu tiada lain, dari hiasan orang yang berbudi pekerti. Jika engkau punya uang, maka kaligrafimu adalah hiasan. Tapi jika kamu butuh uang, kaligrafimu, sebaik-baiknya sumber usaha".

Menurut ustad Waiji: Kaligrafi sebagai salah satu mata pelajaran yang memiliki disiplin ilmu tersendiri. Sebagai dasar pelaksanaan pendidikan Islam

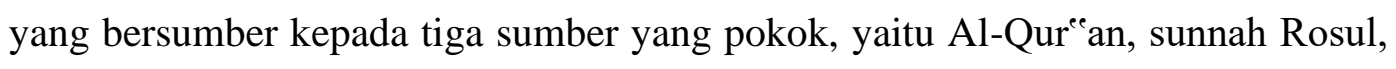
dan ijtihad. Maka dalam membicarakan dasar pelaksanaan pendidikan kaligrafi pun mengikuti sumber yang sama, karena pendidikan Islam.
}

\section{3) Ayat-ayat Al-Qur'an dibaca oleh para qari'}


Qari dalam kamus bahasa Indonesia adalah pembaca Alquran laki-laki sedangkan qari'ah adalah pembaca Al-quran perempuan (Hasan Alwi, 2007: 916). Menurut bahasa qari dan qari'ah adalah pembaca, dan yang dimaksud adalah pembaca Al-quran di depan publik dengan pertimbangan kecakapannya di bidang tajwid. Dari ini mengandung pengertian sejumlah otoritas yang pertama kali merumuskan bacaan Al-quran meliputi vokalisasi, puktuasi dan sebagainya (Ahsin W. Al-Hafidz, 203: 234).

Tartil Alquran adalah membacanya dengan perlahan-lahan sambil memperjelas huruf-huruf berhenti dan memulai (Ibtida') sehingga pembacan dan pendengarnya dapat memahami dan menghayati kandungan pesan-pesannya.

Menurut hasil wawancara penulis dengan salah satu stadzah di Pesantren Darul Arafah Raya yaitu dengan ustadzah Sri Wahyuni terdapat beberapa aspek pokok seni baca Al-quran yang diterapkan di di Pesantren Darul Arafah Raya yaitu: Adab, Fashohah, Suara, Lagu, Bernafas, Tajwid.

Menurut beliau adapun jenis macam lagu yang berkembang saat ini antara lain: Lagu bayati/husaini terbagi menjadi lima yaitu qoror, nawa, syuri, tawab, jawabul jawab.

a) Lagu shoba terbagi dua yaitu maal 'ajam (ajami asyiroh) dan quflah bastanjar.

b) Lagu hijaz terbagi tiga yaitu kard, kard kurd, kurd.

c) Lagu nahawan terbagi tiga yaitu nakris, 'usyaq, jawab (quflah mahur).

d) Lagu Rast terbagi empat yaitu, rast ala nahwa, rast syabir (quflah mahur), zanjirin, salalim (suud dan nuzul).

e) Lagu jiharka terbagi dua yaitu nawa (nada awal jiharka), Jawab (nada tinggi jiharka).

f) Lagu shika terbagi empat yaitu Iraq (fariasi), turki (nada tinggi shika), raml (nada minor), huzami (quflah)an (M. Misbachul Munir, 1995: 9596).

\section{4) Studi living Hadis di pesantren Darul Arafah Raya}


Dari hasil penelitian penulis beberapa gambaran Living Hadis yang keberadaannya sering kita jumpai di lingkungan pesantren bahkan dimasyarakat umum. Menurut penulis 'living hadis tidak hanya menyangkut dengan fen omena yang muncul dalam lingkungan pesantren akan tetapi menyangkut juga dengan praktek sosial keagamaan sebagai bentuk pengamalan hidup sehari-hari. Praktek tersebut didasarkan pada pengamalan hadis sebagai sumber inspirasi. Living hadis juga tidak hanya terpaku pada praktek belaka akan tetapi juga menyangkut tentang pengetahuan, pandangan, perasaan, dan pengalaman masyarakat setempat".

Berdasarkan hasil wawancara penulis dengan salah satu ustadz di Pesantren Darul Arafah Raya beliau mengatakan" Ada tiga model variasi living hadis yaitu tradisi tulis, tradisi lisan, dan tradisi praktek. Tradisi tulis biasanya dalam bentuk tulisan yang terpampang ditempat-tepat strategis dan diyakini bahwa isi tulisan berasal dari Nabi. Tradisi lisan sering muncul bersamaan dengan prakek yang dijalankan oleh masyarakat. Misalnya tradisi yang ada di Pesantren Darul Arafah yaitu: mengucapkan salam ketika berpapasan dijalan, membaca surat Al-ikhllas, Al-falaq, An-nas dan ayat kursi sebelum istirahat pada malam hari.

Dengan demikian, living hadis adalah satu bentuk resepsi (penerimaan, tanggapan, respon) atas teks hadis yang dilakukan oleh seseorang atau kelompok yang terwujud dalam praktik/ritual/tradisi/ perilaku masyarakat.

\section{5) Nilai-nilai Pendidikan di lingkungan Pesantren Darul Arafah Raya}

Berdasarkan temuan penulis ketika melakukan observasi mengenai nilainilai yang hidup di lingkungan Pesantren Darul Arafah Raya adalah sebagai berikut:

\section{a. Religius}

Religius bermakna perilaku yang patuh atau taat dalam koridor agama yang dianutnya, sikap toleran terhadap pemeluk agama lain, dan hidup rukun dengan pemeluk agama lain. Nilai-nilai religius ini sangat penting bagi orangorang muslim dalam menjalankan kehidupannya, terkhusus kepada peserta didik 
dan menjadi sikap hidup yang mengacu pada tatanan dan larangan sikap yang telah diatur atau ditetapkan oleh Yang Maha Kuasa yaitu Allah swt.

Berdasarkan hasil wawancara Penulis dengan Ustad Novi, beliau mengatakan:

\begin{abstract}
"Nilai religius pada Pesantren Darul Arafah dapat di perhatikan dari adanya kegiatan atau kebiasaan memulai dan mengakhiri setiap proses pembelajaran di dalam kelas dengan berdoa terlebih dahulu. Hal itu dilakukan agar supaya aktivitas di dalam proses pembelajaran dapat memperoleh berkah dan ridho dari yang maha pencipta yaitu Allah swt. Agar ilmu yang dipelajari dapat memberikan manfaat terutama kepada dirinya sendiri maupun orang lain, bagi bangsa maupun negara kita yang tercinta yaitu Indonesia".
\end{abstract}

Indikator nilai religiusitas yang terdapat pada santri Darul Arafah yaitu dengan pelaksanaan ibadah sholat secara berjama'ahu secara rutin. Sebagaimana dikatakan oleh sri: "Melalui bimbingan atau arahan dari ustad maupun ustadzah menerapkan kebiasaan melaksanakan shalat di masjid secara berjamaah peserta didik diharapkan mampu mengembangkan nilai-nilai karakter yaitu nilai religius sekaligus dapat membangun semangat kerjasama dengan siapa saja terutama teman sendiri. Shalat berjamaah yang dilakukan oleh peserta didik mempunyai banyak manfaat. Diantaranya adalah dapat menjalin hubungan silaturrahmi dan persaudaraan yang baik diantara para peseta didik sehingga dapat menutup timbulnya benih-benih permusuhan diantara peserta didik".

\title{
b. Disiplin
}

Disiplin bermakna asas ketaatan atau kepatuhan terhadap peraturan atau regulasi yang ditetapkan dan disepakati. Adapun tujuan kedisiplinan itu di lingkungan pendidikan agar peserta didik dapat mengembangkan kepribadiaanya supaya mampu berperilaku tertib sesuai dengan peraturan yang berlaku khususnya pada lingkungan pesantren.

Terkait kedisiplinan maka pesantren sangat tegas dalam memberikan sanksi kepada peserta didik bagi yang melanggarnya. Temuan peneliti terhadap sanksi tersebut adalah sebagai berikut:

1) Ditegur. Teguran ini dilakukan secara bertahap melalui lisan terhadap santri yang melakukan pelanggaran terhadap ketentuan atau aturan yang 
berlaku di Pesantren. Biasanya kesalahan ini berupa kesalahan kecil atau untuk kesalahan yang pertama.

2) Ta'dzir. Sanksi ini berupa sanksi yang bersifat edukatif, misalnya sanksi membuat rangkuman buku tertentu, menerjemahkan tulisantulisan bahasa Inggris/Arab dan lain-lain. Biasanya sanksi ini diberikan kepada santri yang terlambat masuk ke kelas.

3) Berdiri di depan pintu kelas. Santri disuruh berdiri sampai pergantian mata pelajaran atau sampai istirahat.

4) Santri dipulangkan kepada orang tuanya. Biasanya ini merupakan kesalahan yang berat

5) Santri dipanggil beserta kedua orang tuanya agar yang bersangkutan membuat perjanjian dihadapan orang tua mereka agar tidak mengulangi lagi.

\section{c. Tekun}

Tekun berati gigih atau rajin. Tekun juga berarti bersungguh-sungguh dalam melaksanakan sesuatu. Sikap tekun ini biasanya adalah orang yang selalu menghargai waktu. Orang yang tekun akan sangat kehilangan waktu apabila tidak dimanfaatkan untuk kebaikan. Dalam bekerja orang tekun akan selalu berhati-hati dan selalu ingin menghasil karya yang memuaskan.

Ketika santri sudah memiliki sikap tekun ini maka otomatis keberhasilan akan menghampirinya. Dalam Islam tekun bisa dimaknai dengan kata 'mujahadah' yang berarti 'sungguh-sungguh'. Mujahadah ini adalah perbuatan nabi dan orang sholeh, karena mujahadah adalah perintah Allah swt. Manusia cukup berusaha dengan sebaik-baiknya masalah hasilnya maka serahkan kepada Allah swt. Ini sesuai dengan firman Allah swt, yang terdapat pada QS. Ali Imran ayat 159 , yang menjelaskan:

Artinya: Maka disebabkan rahmat Allah-lah kamu berlaku lemah lembut terhadap mereka. Sekiranya kamu bersikap keras lagi berhati kasar, tentulah mereka menjauhkan diri sekelilingmu karena itu ma'afkanlah mereka, mohonkanlah ampun bagi mereka, dan bermusyawaratlah dengan mereka pada urusan itu. kemudian apabila kamu telah membulatkan tekad, maka bertawakkallah kepada Allah swt. Sesungguhnya Allah swt., menyukai orangorang yang bertawakkal kepadaNya. 
Berdasarkan hasil wawancara dengan ustadz di Pesantren tersebut ada beberapa metode yang dilakukan untuk meningkatkan ketekunan peserta didik yaitu:

1) Santri diminta untuk selalu mengkoreksi pekerjaan mereka.

2) Memuji dan memberi apresiasi kepada santri.

3) Memberi stimulus kepada santri agar meningkat motivasi mereka.

4) Melakukan pendekatan kepada santri yang berbasis keilmuan.

5) Guru harus tampil dihadapan santri laksana pelayan.

Berdasarkan keterangan di atas maka penulis memberikan analisis bahwa cara tersebut mampu membuat santri berprestasi dan membuat tingkat intelegensi dan kepercayaanya akan meningkat.

d. Rasa Ingin Tahu

Rasa ingin tahu adalah sikap ingin tahu seseorang akan segala hal seperti eksplorasi, investigasi, dan belajar. Rasa ingin tahu ini didasari oleh rasa penasaran yang tinggi, sehingga untuk menghilangkan rasa penasaran itu, ia berusaha untuk mencari tahu akan hal tersebut. Indikator rasa ingin tahu yang terdapat pada santri Darul Arafah adalah dengan banyaknya pertanyaan diajukan, sehingga timbul rasa penasaran lalu mereka menggali, menjelajahi kemudian menyelidiki, mereka akan merasa puas apabila mereka menemukan jawaban dari rasa penasaran itu.

Berdasarkan hasil wawancara Penulis dengan Ustadzah icut: "Rasa ingin tahu peserta didik di Pesantren Darul Arafah terlihat pada aktivitas yang selalu bertanya ketika proses pembelajaran, pada saat pendidik membacakan materi sajar ataukah sementara menjelaskan pelajaran dan bahkan ketika guru menulis dipapan tulis".

Menurut ustadzah Cena S.Pd selaku guru bahasa Inggris di Pesantren Darul Arafah ada beberapa metode yang harus dilakukan guru untuk meningkatkan rasa ingin tahu peserta didik yaitu sebagai berikut:

1) Guru wajib memberi peluang dan membuka pikiran santri terhadap hal-hal yang baru dari sesuatu yang sudah mereka pelajari. 
2) Guru wajib menstimulus santri agar selalu bertanya.

3) Guru wajib memberikan pembelajaran terhadap santri agar mudah bosan untuk belajar dan menuntut ilmu.

4) Guru wajib memberikan pembelajaran kepada santri untuk melihat dan menyadari bahwa belajar itu adalah sesuatu yang menyenangkan.

5) Guru wajib memberikan pembelajaran tentang pengetahuan baru, supaya selalu update terhadap pengetahuan yang baru tersebut.

e. Peduli

Peduli adalah suatu sikap ataupun tindakan untuk memberi bantuan ataupun pertolongan berupa materi ataupun non materi pada orang lain yang membutuhkannya. Peduli merupakan sikap empati kepada sesama. Orang yang memiliki kepedulian sosial yang tinggi sudah pasti memiliki banyak kawan dan relasi.

Hasil wawancara penulis kepada ustazah cena S.Pd beliau mengatakan: "Salah satu nilai peduli yang diajarkan oleh ustad dan ustadzah di lingkungan pesantren adalah pentingnya memiliki sikap kepedulian terhadap sesama. Hal tersebut kami terapkan pada kehidupan nyata melalui sumbangan peserta didik. Ketika peserta didik sakit dan dirawat di rumah sakit biasanya diberikan sumbangan uang, ketika peserta peserta didik mengalami musibah kematian juga diberikan sumbangsi uang”.

Untuk memunculkan rasa peduli santri terhadap sesama ada beberapa metode yang dilakukan oleh para ustadz dan ustadzah adalah sebagai berikut:

1) Mempertegas pada santri akan keutamaan sikap peduli dan tanggung jawab.

2) Memberikan pengajaran akan keutamaan sikap kepedulian sosial.

3) Melatih dan membiasakan santri untuk mengamalkan prilaku terpuji terutama sikap tanggung jawab dan kepedulian sosial.

Apabila santri dibiasakan melakukan sikap peduli dan kemudian diwujudkan dalam kehidupan sehari-hari, maka akan tumbuh secara sendirinya sikap kepedulian itu tanpa ada proses pemikiran dalam melakukan sesuatu. 


\section{f. Tanggung Jawab}

Tanggung jawab adalah seperangkat prilaku seseorang dalam menjalankan tugas serta kewajiban terhadap diri sendiri, masyarakat, lingkungan alam, sosial, dan terlebih kepada Tuhan yang Maha Esa. Nilai yang terkandung dalam tanggung jawab ini sangat dibutuhkan oleh masyarakat karena menyangkut masalah tugas yang harus dijalankan atau dilaksanakan dengan sebaik baiknya.

Terkait dengan sikap tanggung jawab ini maka tanggung jawab santri yang ada di Pesantren Darul Arafah dapat dianalisis pada ketekunan atau keseriusan santri dalam mengerjakan pekerjaan yang dibebankan kepada mereka. Contohnya yang terdapat di lingkungan kelas, maka ditemukan bahwa peserta didik tidak ada yang tidak mengerjakan pekerjaan rumah (PR). Ini disebabkan karena peraturan yang ditetapkan oleh kepala sekolah dan unsur-unsurnya dijalankan dengan tegas dan disiplin. Maka dapat diketahui bahwa substansi dari nilai tanggung jawab terlihat pada kemampuan peserta didik dalam menjalankan peraturan yang telah ditetapkan yaitu berupa menjalankan tugas individu maupun kelompok atau menjalankan amanah yang diberikan guru kepada peserta didik seperti tugas piket menyapu, menyelesaikan pekerjaan rumah (PR) dan bertanggung jawab jika melakukan kesalahan-kesalahan di lingkungan sekolah.

Menurut hasil wawancara peneliti dengan ustad fauzan S.Pd nilai-nilai yang ditanamkan di Pondok Pesantren Darul Arafah adalah dituangkan dalam bentuk skema sebagai berikut: 


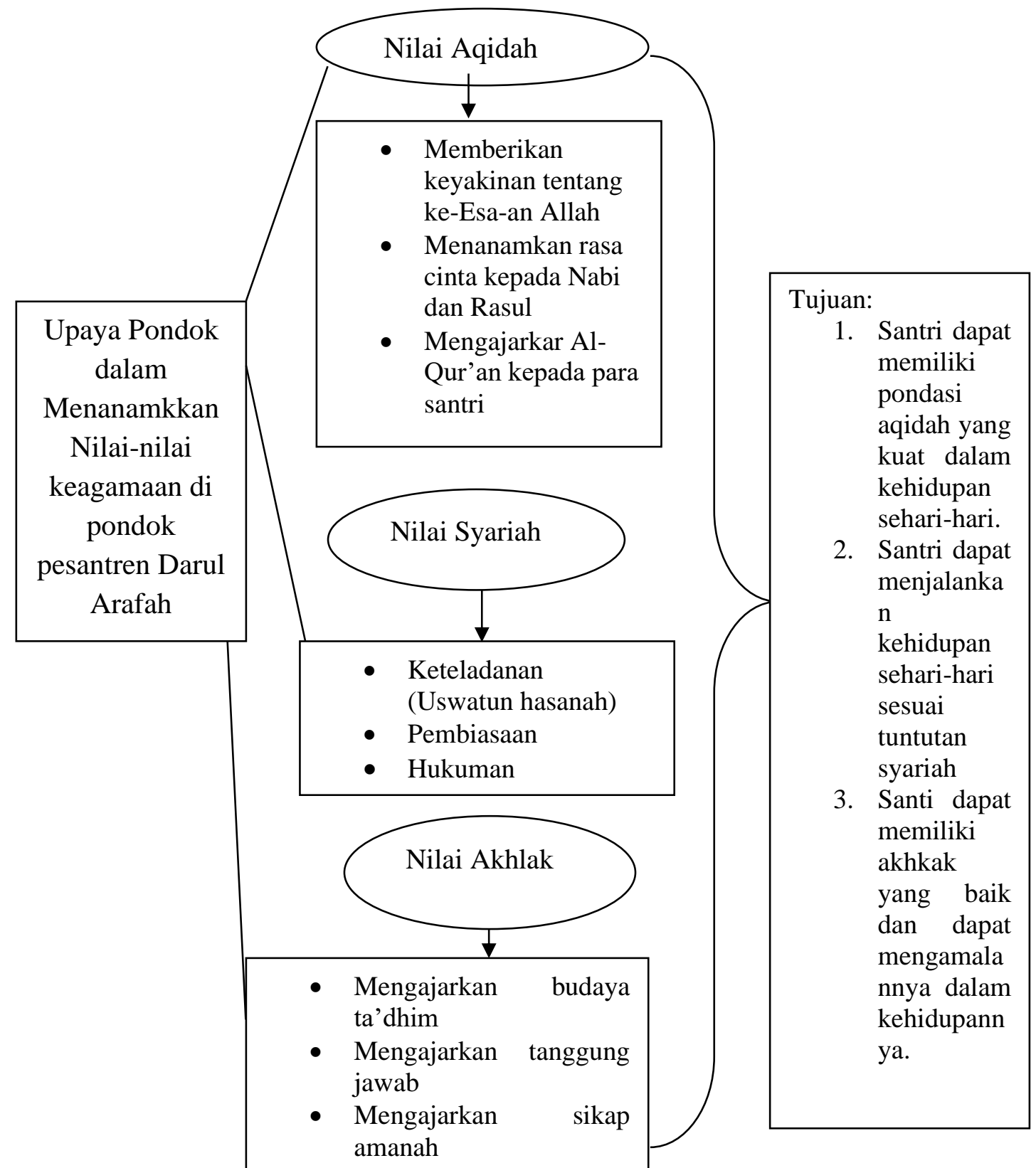

Gambar 2. Nilai-nilai Pendidikan di lingkungan Pesantren Darul Arafah Raya

Sedangkan menurut hasil wawancara peneliti dengan ustad Nirwansyah M.Pd beliau menuturkan nilai-nilai yang hidup di lingkungan Pesantren Darul Arafah Raya adalah dibagi menjadi 4 nilai yaitu:

1. Nilai tauhid, yaitu proses pemenuhan fitrah bertauhid, fitrah bertauhid merupakan unsur hakiki yang melekat pada diri manusia sejak penciptaannya. 
2. Nilai ibadah, yaitu pengabdian ritual sebagaimana diperintahkan dan diatur di dalam al-quran dan sunnah.

3. Nilai akhlak, yaitu norma-norma baik dan buruk yang menentukan kualitas pribadi manusia.

4. Nilai Kemasyarakatan, yaitu mencakup pengaturan pergaulan hidup manusia diatas bumi, misalnya pengaturan tentang benda, ketatanegaraan, hubungan antarnegara, hubungan antar manusia dalam dimensi sosial, dan lain-lain.

Jadi, dari hasil wawancara di atas penulis menyimpulkan bahwa nilai-nilai yang ditanamkan dan hidup dilingkkungan pesantren Darul Arafah Raya adalah nilai-nilai yang mengandung atau nilai-nilai yang mengajakan para santri tentang adanya Tuhan, pentingnya beribadah dalam hidup, setiap manusia harus memiliki akhlak yang baik dan juga mengajarkan para santri akan pentingnya hidup bermasyarakat.

\section{Kesimpulan}

Adapun serangkaian penelitian yang dibentangkan di atas tentang Studi Living Alquran dan Hadis dapat di tarik kesimpulan di pondok pesantren Darul Arafah Raya, maka dapat penulis simpulkan bahwa:

1. Studi living al-qur'an di pesantren darul arafah raya di antaranya adalah: Al-Qur'an dibaca rutin dan diajarkan di tempat-tempat ibadah, AlQur'an senantiasa dihafalkan, Menjadikan potongan ayat, satu atau beberapa ayat tertentu dikutip dan dibentuk kaligrafi, dan Ayat-ayat AlQur'an dibaca oleh para qari,

2. Studi living hadis di pesantren darul arafah raya merawat otentitas tradisi tulisan, tradisi lisan, dan tradisi praktik.

3. Nilai-nilai pendidikan di lingkungan pesantren darul arafah raya berupa Nilai tauhid, Nilai ibadah, Nilai akhlak, dan Nilai kemasyarakatan 


\section{Referensi}

Ahsin W. Al-Hafidz, 2003, Kamus Ilmu Al-Quran, Cet. 3, (Jakarta: Amzah)

Ahsin, 2005, Bimbingan Praktis Menghafal Al-Qur'an, Ed. 1, Cet, III, (Jakarta: Bumi Aksara)

Al-Hafidz Dan Ahsin Wijaya, 2008, Bimbingann Praktis Menghafal Al Qur'an (Jakarta: Bumi Aksara).

Adrika Fithrotul Aini, Living Hadis Dalam Tradisi Malam Kamis Majelis Shalawat Diba' Bil-Mustofa, Ar-Raniry: International Journal Of Islamic Studies 2 (1) (2014):221-235

Bukhari, Al, Sahih Al-Bukhari. (Kairo: Dar Al-Syu'ub, T.Th) Juz VII.

Daroini, Muhammad Dkk (Ed.), 2011, Wardah : Warta Darularafah Edisi Ke VIII (Medan : Yayasan Pendidikan Darularafah)

Suwadi Dkk, Panduan Penulisan Skripsi, 2012 Yogyakarta: Jurusan PAI UIN Sunan Kalijaga

Dzahabi Husein Muhammad Al, Al-Tafsir Wa Al-Mufassirun. (Beirut: Dar AlFikr, T.Th) Jilid I.

Departemen Agama RI, Departemen Agama RI, N.D. Lihat Juga Mukti Ali, “Dampak Perda No.9 Tahun 2007 Tentang Baca Tulis Al-Qur'an Di SMK Negeri Kabupaten Pasaman Barat" (IAIN Walisongo, 2010).

Hasan Alwi, Kamus Besar Bahasa Indonesia, 2007, Cet. 4 (Jakarta: Balai Pustaka)

Hermawan Didik, "Penerapan Metode Ummi Dalam Pembelajaran Al-Qur'an" Profetika: Jurnal Studi Islam 19 (1) (2018): 27-35.

Ilyas Yunahar. Kuliah Ulumul Qur'an, (Yogyakarta: ITQAN Publishing, 2013). Kartika, Rika Nurman. "Pelaksanaan Gerakan Masyarakat Magrib Mengaji Di Nagari Lubuk Basung Kabupaten Agam” Journal Of Civic Education 1 (2) (2018): 141-148.

M. Mansur Et Al, 2007, Metodologi Penelitian Living Qur'an Dan Hadis, (Yogyakarta: Teras)

Mohamed Shaed Mathee, A Critical Reading Of Fazlur Rahman's Islamic Methodology In History: The Case Of The Living Sunnah (South Africa: 
Dissertation Of University Of Cape Town, 2004). Abdul Haris, Hermeneutika Hadis (Studi Atas Teori Pemahaman Hadis Menurut Fazlur Rahman Dan Muhammad Syahrur) (Yogyakarta: Disertasi UIN Sunan Kalijaga, 2011)

Moleong, Lexy J, 2010, Metodologi Penelitian Kualitatif, (Bandung: Remaja Rosdakarya)

Munir, Misbachul M, 1995, Pedoman Lagu-Lagu Tilawatil Quran Dilengkapi Dengan Tajwid Dan Qasidah, Cet. 1 (Surabaya: Apollo)

Mustaqim, Dkk, 2008, Paradigma Interaksi Dan Interkoneksi Dalam Memahami Hadis, (Yogyakarta: Sukses Ofset)

Najwah Nurun, Tawaran Metode Dalam Studi Living Sunnah, Dalam Sahiron Syamsuddin, Metodologi Penelitian Living Qur'an Dan Hadis, (Yogyakarta: TH Press Dan Teras: 2007)

Nasution Fahmi Ismail Arrauf, "Menangkap Pesan Tuhan:Urgensi Kontekstualisasi Alquran Melalui Hermeunetika", Jurnal At-Tibyan, 3 (2) (2018): 224-235.

Sahiron Syamsuddin, "Ranah-Ranah Penelitian Dalam Studi Al-Qur'an Dan Hadis,” Dalam Sahiron Syamsuddin (Ed.), 2007)., Metode Penelitian Living Qur'an Dan Hadis, (Yogyakarta: TH-Press)

Syaamil Quran. Hijaz Terjemahan Tafsir Perkata. (QS, 7:204) PT. Sigma Examedia Arkanleema.

Munjahid, 2007, Strategi Menghafal 10 Bulan Khatam: Kiat-Kiat Sukses Menghafal Al-Quran (Yogyakarta: Idea Press)

Syaamil Quran. Hijaz Terjemahan Tafsir Perkata.( QS:15: 9) PT. Sigma Examedia Arkanleema.

Sayyid Muhammad, Islamic Methodology In History, 1994, (India: Adam Publisher And Distributors)

Shihab Quraish M., Mukjizat Al Qur'an, (Bandung:Mizan, 1997). Moh. Ba'asyien Arsyad, "Beberapa Segi Kemukjizatan Alquran”, Jurnal Hunafa 5 (1) (2008): 117-128. 
Siregar, Ihsan. 'Penerapan Metode Iqro' Dan Pengaruhnya Terhadap Kemampuan Membaca Al-Qur'an Murid MDA Muhammadiyah Bonan Dolok" Almuaddib: Jurnal Ilmu-Ilmu Sosial Dan Keislaman 3 (1) (2018): 1-28.

Suryadilaga Alfatih M., 2007, Metodologi Penelitian Living Qur'an Dan Hadis, (Yogyakarta: Teras)

Tanasa Sulastri, Yahii Kasim, Damhuri Damhuri, "Manajemen Pengembangan Karakter Berbasis Spiritual Quotient Dalam Mengatasi Isu-Isu Radikalisme Di Madrasah Aliyah", Al Minhaj Journal, 2 (1) (2019): 1-19.

W. Al-Hafidz Ahsin, 2003, Kamus Ilmu Al-Quran, Cet. 3 (Jakarta: Amzah) 